Study the possible role of CMV and EBV infections to initiate high blood pressure in some groups of hypertensive Iraqi patients

Jasim M. Muhsin

\title{
Study the possible role of CMV and EBV infections to initiate high blood pressure in some groups of hypertensive Iraqi patients
}

\author{
Jasim M. Muhsin \\ Department of Medical Laboratory Technologies -Health and Medical Technology College \Baghdad \\ Middle Technical University
}

Received: 28 February 2016

Accepted: 12 June 2016

\section{$\underline{\text { Abstract }}$}

The main purposes of this study were to find out the possible correlation of CMV \& EBV infections with high blood pressure initiation in some groups of hypertensive Iraqi patients, also to determine the relationship of between EBV \& CMV infections with some clinico pathological factors which were involved in this study. The present study was designed as a prospective research with (90) serum samples as (45) specimens from hypertensive patients (cases) and another (45) specimens from individuals with normal blood pressure (controls), collected from Baghdad teaching hospital \& teaching laboratories $\backslash$ Medical city $\backslash$ Baghdad, from the period of March (2015) to April (2015). All samples had been subjected into ELISA test for CMV IgG \& EA EBV IgG detection in private laboratory, from the period of 1 st -8 th of April (2015). Statistically significant differences detected in the presence of IgG to CMV $(p=0.006)$ and EBV-EA IgG $(p=0.01)$ regarding to the negative results of selected study groups. According to the history of heart diseases it was with high significant difference $\quad(p=$ 0.000) regarding to the CMV IgG positive results comparing with the presence of EA EBV $\operatorname{IgG}(\mathrm{p}=0.084)$. Interestingly, the positive results of CMV IgG \& EA EBV IgG were associated with hypertension progression. Finally, the EBV \& CMV infection maybe play a significant role in the increasing of the blood pressure as a suitable co-factors.

Key words: CMV, EBV, Hypertension 
Study the possible role of CMV and EBV infections to initiate high blood pressure in some groups of hypertensive Iraqi patients

\title{
Jasim M. Muhsin
}

دراسة الدور المحتمل للإصابة بالفيروس المضخم للخلايا و فيروس ابثتاين بار في ارتفاع ضغط الدم في بعض الفئات من المرضى العراقيين المصابين بارتفاع ضغط الدم

\author{
جاسم محمد محسن \\ قسم تقنيات التحليلات المرضية ـ كلية التقنيات الصحية والطبية ـ الجامعة التقنية الوسطى
}

\section{الخلاصة}

تمثلت الأهداف الرئيسية لهذه الدر اسة لمعرفة العلاقة المحتلة للإصابة بفيروس المضخم للخلايا و فيروس ابشتاين بار مع بدء ارتفاع ضغط الدم في بعض الفئات من المرضى العر اقيين المصابين بارتفاع ضغط الدم ، و أيضا لتحديد علاقة الإصابة بين كلا من EBV و مMV مع بعض العوامل الإكلينيكية المرضية التي ضمنتها هذه الدر اسة. وتم تصميم هذه الدراسة كبحث محتمل الحدوث ومن (90) من عينات مصل الدم كـ (45) عينة من مرضى ارتفاع ضغط الدم (الحالات) و (45) عينة أخرى من الأفراد ذوي ضغط الدم العادي (السيطرة) ، و التي قد تم جمعها من مستشفى بغداد التعليمي و المختبرات

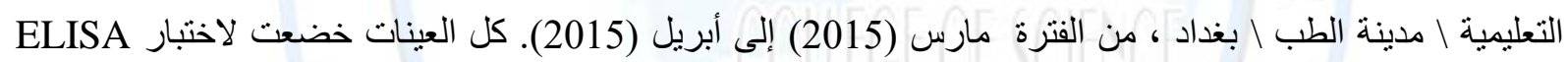
للكثف عن EBV EA-IgG CMV-IgG في مختبر خاص ، ومن الفترة 1 - 8 أبريل (2015). فروق ذات دلالة إحصائية في الكثف عن وجود EBV EA-IgG و (p=0.006 CMV-IgG (p=0.01) نسبتاً للنتائج السلبية لمجمو عات الدراسة المختارة. وطبقا إلى تاريخ الإمر اض القلبية كان مع اختلاف كبير جدا (0.000 = p) نسبتاً للنتائج ألايجابية لـ مقارنتاً مع وجود CMV-IgG EBV EA-IgG و CMV-IgG ابشتاين بار ربما يلعبان دورا هاما في زيادة ارتفاع ضغط الدم باعتبار هم من العو امل المشاركة المناسبة لذللك. الكلمات المفتاحية: الفيروس المضخم للخلايا ، فيروس ابشتاين بار ، ارتفاع ضغنط الدام

\section{Introduction}

The Human cytomegalovirus (HCMV) is a one of the family of herpes viruses, with infection rate precede the most common infections with adults population, the seropositive rates estimated from 60-99\% worldwide [1]. After viral acquired infection, the virus persists lifelong with reactivation periodically. Interestingly, HCMV infection is related to heart diseases $[1,5]$. Moreover, several viruses infections are implicated with hypertensive patients with high 
Study the possible role of CMV and EBV infections to initiate high blood pressure in some groups of hypertensive Iraqi patients

\section{Jasim M. Muhsin}

occurrence of atherosclerosis progression[2-5], like HIV-1 and human herpes virus 8 (HHV-8) in primary pulmonary hypertension cases [2-3-4]. The Epstein-Barr virus (EBV), It is a very common viruses within herpes family in men and women population. It is also related to infectious mononucleosis causes. EBV is also linked with some cancer forms, including Burkitt's lymphoma, Hodgkin's lymphoma and central nervous system lymphomas associated with HIV infection. As well as, there is facts that EBV infection is connected with a certain autoimmune diseases. Finally, it can interrelate with primary pulmonary hypertension [5-6-7]. The primary role of both CMV and EBV infection in atherosclerosis initiation and vascular injury, still mysterious yet, many hypotheses tells that they are maybe serves as a cofactors to interrelate with other factors to induce problems of atherosclerosis [7,8-17].

\section{Objectives}

The main purpose of this study were to find out the possible association of CMV and EBV infections with high blood pressure initiation in some groups of hypertensive Iraqi patients, also to determine the relationship of both EBV and CMV infections with some clinico - pathological factors which were involved in this study.

\section{Patients}

A cohort of 90 serum samples $(2 \mathrm{ml})$ has been collected from each selected individual in this study, all sera have been stored in deep freezer (-20) and distributed as (42 females and 48 were males), (45\50\%) hypertensive patients as a study cases and another (45\50\%) normal individuals as controls of study. All the selected study groups were divided into five age groups and most individuals were within the age interval of $(36-45)$ as $(27 \backslash 30 \%)$ followed by the age interval of $(46-55)$ as $(23 \backslash 25.6 \%)$. The clinico - pathological factors which include blood pressure evaluation, history of heart diseases, history of smoking status, cholesterol levels, genders and age of individuals were determined by qualified physician and organized in the medical reports of each selected case in this study. 
Study the possible role of CMV and EBV infections to initiate high blood pressure in some groups of hypertensive Iraqi patients

\section{Jasim M. Muhsin}

\section{Methods}

The procedure was done based upon the manufacturer's instructions of Diagnostic Automation Company \USA - ELISA kits, both of purified CMV and EBV - EA (early antigen) were coated onto the microwells surface. Diluted patient serum was added into wells, and if the CMV-IgG and anti- EBV-EA specific antibodies present then it will interact to the target antigen, then all unbound contents were removed away by wishing. Enzyme conjugate adding later, followed by the binding to the antigen-antibody complex. overload enzyme conjugate Horseradish Peroxidase (HRP), was washed off and TMB Chromogenic Substrate (3,3',5,5'Tetramethylbenzidine) was added. The enzyme conjugate catalytic reaction is stopped by $(0.16 \mathrm{M}$ sulfuric acid) at a specific time and the color intensity generated was relative to the amount of IgG specific antibody in the sample. The results were evaluated by a microwell reader and compared in a parallel manner with calibrator and controls [9].

\section{Statistical Analysis}

The association of high blood pressure with the detection of CMV IgG and EBV EA IgG were analyzed using Chi-square test $\backslash$ SPSS ver. 18.0 to detect the significances among the studied variables.

The (P-value) of the comparison of significant in any test were:

$\mathrm{S}=$ Significant difference $(\mathrm{P}<0.05), \mathrm{HS}=$ Highly Significant difference $(\mathrm{p}>0.0001)$

$\mathrm{NS}=$ Non Significant difference $(\mathrm{P}>0.05)$. [18]

\section{$\underline{\text { Results }}$}

\section{General results interpretation of the studied clinico - pathological factors}

According to the Table (1): the study groups were divided into (hypertensive patients) by (45\100\%) as cases of the study and another (45\100\%) normal individuals as controls with high significant differences between them $(\mathrm{p}=0.000)$. Genders distribution was as $(48153.3 \%)$ males and (42 46.7\%) females with no significant difference ( $p=0.39$ ), in addition to, most of selected individuals were in $(36-45)$ followed by $(46-55)$ of the age intervals with no significant differences among age categories distribution $(\mathrm{p}=0.67)$. Smoking status distributed as (44\48.9\%) individuals with regular smoking activity while (46151.1\%) as non-smoking 
Study the possible role of CMV and EBV infections to initiate high blood pressure in some groups of hypertensive Iraqi patients

\section{Jasim M. Muhsin}

individuals with no significant differences comparing to the non-smoking ones $(\mathrm{p}=0.39)$. There were significant differences in the abnormal cholesterol level as $(\mathrm{p}=0.005)$ regarding to the normal cholesterol in some selected study cases. Generally, the positive results for CMV IgG was $(49 / 54.4 \%)(p=0.006)$ and for EBV EA IgG was (59\65.6) $(\mathrm{p}=0.01)$ with significant differences in the negative results for the same viruses.

Table (1) : Comparison among the total of studied Clinico - pathological factors

\begin{tabular}{|c|c|c|c|}
\hline \multicolumn{2}{|c|}{ Clinico - pathological factors } & No. / Percentages & p-value \\
\hline \multirow[t]{3}{*}{ Study Groups } & Hypertensive Patients & (45) $50 \%$ & \multirow{3}{*}{$\begin{array}{c}0.000<0.001 \\
\text { HS }\end{array}$} \\
\hline & Normal Individuals & (45) $50 \%$ & \\
\hline & Total & (90) $100 \%$ & \\
\hline \multirow[t]{3}{*}{ Genders } & Males & (48) $53.3 \%$ & \multirow{3}{*}{$\begin{array}{c}0.39>0.05 \\
\text { NS }\end{array}$} \\
\hline & Females & (42) $46.7 \%$ & \\
\hline & Total & (90) $100 \%$ & \\
\hline \multirow[t]{5}{*}{ Age Groups } & $(25-35)$ & (22) $24.4 \%$ & \multirow{5}{*}{$\begin{array}{c}0.67>0.05 \\
\text { NS }\end{array}$} \\
\hline & $(36-45)$ & (27) $30 \%$ & \\
\hline & $(46-55)$ & (23) $25.6 \%$ & \\
\hline & $\geq 56+2$ & (18) $20 \%$ & \\
\hline & Total & (90) $100 \%$ & \\
\hline \multirow[t]{3}{*}{ Smoking Status } & Yes & (44) $48.9 \%$ & \multirow{3}{*}{$\begin{array}{c}0.39>0.05 \\
\text { NS }\end{array}$} \\
\hline & No & (46) $51.1 \%$ & \\
\hline & Total & (90) $100 \%$ & \\
\hline \multirow{3}{*}{$\begin{array}{l}\text { Heart diseases } \\
\text { history }\end{array}$} & Yes & (41) $45.6 \%$ & \multirow{3}{*}{$\begin{array}{c}0.000<0.001 \\
\text { HS }\end{array}$} \\
\hline & No & (49) $54.4 \%$ & \\
\hline & Total & (90) $100 \%$ & \\
\hline \multirow[t]{3}{*}{ Cholesterol Levels } & Normal & (53) $58.9 \%$ & \multirow{3}{*}{$\begin{array}{c}0.005<0.05 \\
\mathbf{S}\end{array}$} \\
\hline & Abnormal & (37) $41.1 \%$ & \\
\hline & Total & (90) $100 \%$ & \\
\hline \multirow[t]{3}{*}{ CMV IgG } & Positive & (49) $54.4 \%$ & \multirow{3}{*}{$\begin{array}{c}0.006<0.05 \\
\mathbf{S}\end{array}$} \\
\hline & Negative & (41) $45.6 \%$ & \\
\hline & Total & (90) $100 \%$ & \\
\hline \multirow[t]{3}{*}{ EBV EA IgG } & Positive & (59) $65.6 \%$ & \multirow{3}{*}{$\begin{array}{c}0.01<0.05 \\
\mathbf{S}\end{array}$} \\
\hline & Negative & (31) $34.4 \%$ & \\
\hline & Total & (90) $100 \%$ & \\
\hline
\end{tabular}


Study the possible role of CMV and EBV infections to initiate high blood pressure in some groups of hypertensive Iraqi patients

\section{Jasim M. Muhsin}

\section{Results Comparison between Hypertensive patients and Normal individuals}

As shown in Table (2): the study cases (hypertensive patients) distributed as (23125.6\%) females followed by (22124.4) males with no significant differences in genders distribution ( $\mathrm{p}=0.39)$, in addition to, most hypertensive patients were in $(46-55)$ followed by $(36-45)$ of the age intervals with no significant differences in the age categories distribution $(\mathrm{p}=0.67)$, according to the smoking hypertensive patients, They were as (24126.7\%) individuals from the selected study groups with no significant differences comparing to the non-smoking individuals $(\mathrm{p}=0.39)$. Furthermore, there were significant differences in the abnormal cholesterol level as $(\mathrm{p}=0.005)$ between the hypertensive patients and the individuals with normal blood pressure. Finally, the hypertensive patients were with positive results for CMV IgG as (31/34.4\%) $(\mathrm{p}=0.006)$ and EBV EA IgG as (35\38.9) $(\mathrm{p}=0.01)$ with significant differences comparing with negative results.

Table (2): Comparison between Hypertensive patients and Normal Individuals according to CMV IgG, EBV EA-IgG and some others clinico- pathological factors

\begin{tabular}{|c|c|c|c|c|c|c|}
\hline \multirow{2}{*}{\multicolumn{2}{|c|}{ Characteristics }} & \multicolumn{4}{|c|}{ Study Groups } & \multirow[t]{3}{*}{ p-value } \\
\hline & & \multicolumn{2}{|c|}{ Hypertensive } & \multicolumn{2}{|c|}{ Normal } & \\
\hline & & NO. & $\%$ & NO. & $\%$ & \\
\hline \multirow{5}{*}{ Age Groups } & $(25-35)$ & 10 & 11.1 & 12 & 13.3 & \multirow{5}{*}{$\begin{array}{c}0.67>0.05 \\
\text { NS }\end{array}$} \\
\hline & $(36-45)$ & 13 & 14.4 & 14 & 15.6 & \\
\hline & $(46-55)$ & 14 & 15.6 & 9 & 10 & \\
\hline & $\geq 56$ & 8 & 8.9 & 10 & 11.1 & \\
\hline & Total & 45 & $50 \%$ & 45 & $\mathbf{5 0 \%}$ & \\
\hline \multirow[t]{3}{*}{ Genders } & Male & 22 & 24.4 & 26 & 28.9 & \multirow{3}{*}{$\begin{array}{c}0.39>0.05 \\
\mathbf{N S}\end{array}$} \\
\hline & Female & 23 & 25.6 & 19 & 21.1 & \\
\hline & Total & 45 & $50 \%$ & 45 & $50 \%$ & \\
\hline \multirow[t]{3}{*}{ Smoking Status } & Yes & 24 & 26.7 & 20 & 22.2 & \multirow{3}{*}{$\begin{array}{c}0.39>0.05 \\
\text { NS }\end{array}$} \\
\hline & No & 21 & 23.3 & 25 & 27.8 & \\
\hline & Total & 45 & $50 \%$ & 45 & $50 \%$ & \\
\hline \multirow[t]{3}{*}{ Heart diseases history } & Yes & 32 & 35.6 & 9 & 10 & \multirow{3}{*}{$\begin{array}{c}0.000<0.001 \\
\text { HS }\end{array}$} \\
\hline & No & 13 & 14.4 & 36 & 40 & \\
\hline & Total & 45 & $50 \%$ & 45 & $50 \%$ & \\
\hline \multirow[t]{3}{*}{ Cholesterol Level } & Normal & 20 & 22.2 & 33 & 36.7 & \multirow{3}{*}{$\begin{array}{c}0.005<0.05 \\
\mathbf{S}\end{array}$} \\
\hline & Abnormal & 25 & 27.8 & 12 & 13.3 & \\
\hline & Total & 45 & $50 \%$ & 45 & $50 \%$ & \\
\hline CMV IgG & Positive & 31 & 34.3 & 18 & 20 & $0.006<0.05$ \\
\hline
\end{tabular}


Study the possible role of CMV and EBV infections to initiate high blood pressure in some groups of hypertensive Iraqi patients

\section{Jasim M. Muhsin}

\begin{tabular}{|c|c|c|c|c|c|c|}
\hline \multirow{2}{*}{ EBV EA IgG } & Negative & 14 & 15.6 & 27 & 30 & \multirow{2}{*}{ S } \\
\cline { 2 - 6 } & Total & $\mathbf{4 5}$ & $\mathbf{5 0 \%}$ & $\mathbf{4 5}$ & $\mathbf{5 0 \%}$ & \\
\hline \multirow{2}{*}{} & & & & & & \\
\cline { 2 - 6 } & Positive & 35 & 38.9 & 24 & 26.7 & $0.01<0.05$ \\
\cline { 2 - 6 } & Negative & 10 & 11.1 & 21 & 23.3 & \multirow{2}{S}{} \\
\cline { 2 - 5 } & Total & $\mathbf{4 5}$ & $\mathbf{5 0 \%}$ & $\mathbf{4 5}$ & $\mathbf{5 0 \%}$ & \\
\hline
\end{tabular}

3. Relationship of viral infection with previous history of heart diseases in the study Groups

Table (3) : Relationship of Viral infection to the previous history of heart disease between the Hypertensive patients and Normal Individuals

\begin{tabular}{|c|c|c|c|c|c|}
\hline \multirow{2}{*}{\multicolumn{2}{|c|}{ CMV IgG \& EBV EA IgG Results }} & \multicolumn{2}{|c|}{ Heart Diseases History } & \multirow{2}{*}{ Total } & \multirow{2}{*}{ p-value } \\
\hline & & Yes & No & & \\
\hline \multirow{3}{*}{$\begin{array}{l}\text { Positives } \\
\text { CMV IgG }\end{array}$} & Hypertensive patients & $28(57.1 \%)$ & $3(6.1 \%)$ & $31(63.3 \%)$ & \multirow{3}{*}{$\begin{array}{l}0.000<0.001 \\
\text { HS }\end{array}$} \\
\hline & Normal Individuals & $8(16.3 \%)$ & $10(20.4 \%)$ & $18(36.7 \%)$ & \\
\hline & Total & $36(73.5 \%)$ & $13(26.5 \%)$ & $49(100 \%)$ & \\
\hline \multirow{3}{*}{$\begin{array}{l}\text { Negatives } \\
\text { CMV IgG }\end{array}$} & Hypertensive patients & $4(9.8 \%)$ & $10(24.4 \%)$ & $14(34.1 \%)$ & \multirow{3}{*}{$\begin{array}{l}0.02<0.05 \\
\mathbf{S}\end{array}$} \\
\hline & Normal Individuals & $1(2.4 \%)$ & $26(63.4 \%)$ & $27(65.9 \%)$ & \\
\hline & Total & $5(12.2 \%)$ & $36(87.8 \%)$ & $41(100 \%)$ & \\
\hline & & & & 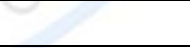 & \\
\hline \multirow{3}{*}{$\begin{array}{l}\text { Positives } \\
\text { EBV EA } \\
\text { IgG }\end{array}$} & Hypertensive patients & $23(39 \%)$ & $12(20.3 \%)$ & $35(59.3 \%)$ & \multirow{3}{*}{$\begin{array}{l}0.000<0.001 \\
\text { HS }\end{array}$} \\
\hline & Normal Individuals & $0(0 \%)$ & $24(40.7 \%)$ & $24(40.7 \%)$ & \\
\hline & Total & $23(39 \%)$ & $36(61 \%)$ & $59(100 \%)$ & \\
\hline \multirow{3}{*}{$\begin{array}{l}\text { Negatives } \\
\text { EBV EA } \\
\text { IgG }\end{array}$} & Hypertensive patients & $9(29 \%)$ & $1(3.2 \%)$ & $10(32.3 \%)$ & \multirow{3}{*}{$\begin{array}{l}0.01<0.05 \\
\mathbf{S}\end{array}$} \\
\hline & Normal Individuals & $9(29 \%)$ & $12(38.7 \%)$ & $21(67.7 \%)$ & \\
\hline & Total & $18(58.1 \%)$ & $13(41.9 \%)$ & $31(100 \%)$ & \\
\hline
\end{tabular}

Regarding to Table (3): Twenty eight (57.1\%) of hypertensive patients were with previous history of heart diseases and positive CMV IgG, Eight (16.3\%) of normal individuals with heart diseases history had positives CMV IgG with highly significant differences between them $(\mathrm{p}=0.000)$, Four of the hypertensive patients $(9.8 \%)$ and only one (2.4\%) of normal individuals 
Study the possible role of CMV and EBV infections to initiate high blood pressure in some groups of hypertensive Iraqi patients

\section{Jasim M. Muhsin}

were with history of heart problems and negative CMV IgG with significant differences between them $(\mathrm{p}=0.02)$. Thirty two $(39 \%)$ of the hypertensive patients were with history of heart problems and had been with positive EBV EA IgG in high significant differences ( $\mathrm{p}=$ 0.000) with the positive results of normal individuals, and there were only nine patients (29\%) had negative EBV EA IgG with significant differences $(\mathrm{p}=0.01)$ comparing with the negative results of normal individuals.

\section{$\underline{\text { Discussion }}$}

This study to explore the issue of some viral infections with hypertension initiation in some groups of Iraqi hypertensive patients and it's followed many global studies. Some earlier medical epidemiological review had anticipated that the CMV infection was connected with restenosis in patients with cardiac transplant surgery, a circumstances in which the arteries of heart's "re-block." as well, this viral infection had been associated to atherosclerosis. nevertheless, in both medical situations, the strategy behind these progression remained as ambiguity and need to resolve [5, 10]."CMV infection, it a very common infection all over the world for human being," A member of the herpes virus family that affects multiple age groups, also its the source of congenital infection, mononucleosis, and other severe infection in transplant patients. After the age of forty, most of the adults people will have interaction with this virus, so many of them will never show symptoms. Once it get entrance into the body, CMV is usually exhibit latent infection until the immune system is weaken then reactivated $[1,11]$. In the first part of the study, there was a highly significant relation of CMV infection with blood pressure problems as proved in many previous studies by some scientists over the world [12-13].

It interestingly and strongly suggest the CMV viral infection with diet of elevated levelcholesterol have the ability to interact collectively to initiate Harding of heart arteries (atherosclerosis), a signal of the CMV viral infection had cause vascular cells inflammation. Regarding to the first investigation established that CMV motivated of making some of diverse inflammatory cytokines like ( IL-6 \& TNF) [13]. A second laboratory analysis found that infection of a mouse kidney cell line with murine CMV led to an increase in the expression of 
Study the possible role of CMV and EBV infections to initiate high blood pressure in some groups of hypertensive Iraqi patients

\section{Jasim M. Muhsin}

the renin enzyme, which has been known to activate the renin-angiotensin system and lead to high blood pressure progression. Clinical isolates of human CMV from the cultured blood vessel cells also produced increased renin expression in vitro[14]. Turning on human genes it one of the viruses capabilities, regarding to this, the CMV is encourage of renin expression, which has been known to concerned directly for causing elevated blood pressure. Some scientists used the ultraviolet light source to virus inactivation, expression of renin did not raise, suggesting that actively replicating virus was causing the increase in renin[12,14]. Over expression of angiotensin 11 and renin that considered as important factors for hypertension progression in humans that noticed in the final experiments as response to CMV infection. Our study seems to point out is that a viral persistent infection in the endothelial cells of vessels is foremost to stimulate the expression of inflammatory cytokines, angiotensin 11 and renin production, which altogether causes elevated blood pressure [12-13,15]. Furthermore, CMV infection linking to blood pressure elevation, in addition to diet with high-cholesterol contents. In fact, the infection induce atherosclerosis in a mouse aorta. This suggested more research to determine the role viral infection with vascular injury $[8,15]$. By enhancing of the releasing and production of the some of pro-inflammatory cytokines many evidence indicates that viral infections even with a low viral load can initiate altogether the atherosclerosis progression and acute coronary events occurrence of $[8,16]$. Evolution of atherosclerosis may interact with these cytokines and different parts of adhesion molecules that are known to play a major role in multiple levels of the heart problems [17]. After reactivation of latent infection, enzyme encodes by EBV called deoxyuridine triphosphate nucleotidohydrolase (dUTPase), as a portion of the production and synthesis of the EBV early proteins. The dUTPase enzyme has the capability to stimulate peripheral blood monocytes to generate pro-inflammatory cytokines like; interleukin-6 (IL-6) and expression of endothelial cell of intercellular adhesion molecule-1 (ICAM-1) [16,17]. Throughout the incomplete cycle of viral replication maybe there is a low viral load and is hard to identify by using ordinary laboratory methods, Then it is possible that dUTPase encoded by EBV induces a pro-inflammatory cascade process. This would account for the ability of EBV with it role in atherogenesis initiation[8-17]. 
Study the possible role of CMV and EBV infections to initiate high blood pressure in some groups of hypertensive Iraqi patients

Jasim M. Muhsin

\section{$\underline{\text { Conclusion }}$}

Unlikely the current study had given us an interesting results about EBV and CMV association with high blood pressure problems, which indicated that both viruses infection maybe play a significant role in the increasing the blood pressure.

\section{Recommendation}

Using advance molecular techniques with heart plaques as a main specimens of laboratory investigations in order to confirm the reality of EBV \& CMV infection roles to initiate high blood pressure, which must be studied with a large Iraqi sample size.

\section{$\underline{\text { References }}$}

1. ICTV. "Virus Taxonomy: 2014 Release". Retrieved 15 June 2015.

2. BioMed Research International, Human Cytomegalovirus and Autoimmune Disease,(2014), Anne Halenius and Hartmut Hengel, Volume 2014 Article ID 472978, 15 pages.

3. Clinical \& Experimental Immunology, Relation of high cytomegalovirus antibody titres to blood pressure and brachial artery flow-mediated dilation in young men: the Cardiovascular Risk in Young Finns Study, 2012, Haarala A1, Kähönen M, Lehtimäki T, Aittoniemi J, Jylhävä J, Hutri-Kähönen N, Taittonen L, Laitinen T, Juonala M, Viikari J, Raitakari OT, Hurme M,167(2): 309-16.

4. Journal of Infectious Diseases, ICONA Foundation Study, CMV co-infection is associated with increased risk of severe non-AIDS events in a large cohort of HIVinfected patients, 2015, Lichtner M, Cicconi P, Vita S, Cozzi-Lepri A, Galli M, Lo Caputo S, Saracino A, De Luca A, Moioli M, Maggiolo F, Marchetti G, Vullo V, d'Arminio Monforte A, 15;211(2) 2015 Jan:178-86.

5. Jundishapur $\mathbf{J}$ Microbiol, Cytomegalovirus Infection and Atherosclerosis in Candidate of Coronary Artery Bypass Graft, 2015 , Habib Heybar, Seyed Mohammad Alavi, Mehdi Farashahi Nejad, and Mahmood Latifi, 8(3), 2015 Mar.

6. Exp Mol Med, EBV and human cancer , 2015 , Young-Hyeh Ko 2014, 47(1), 2015. 
Study the possible role of CMV and EBV infections to initiate high blood pressure in some groups of hypertensive Iraqi patients

\section{Jasim M. Muhsin}

7. BMJ Case Reports, An unusual presentation of cardiac tamponade associated with Epstein-Barr virus infection, 2015, Kai Man Alexander Ho and Sheena C Mitchell, doi:10.1136/bcr-2015-209659.

8. PLoS ONE, Evidence for the Role of Epstein Barr Virus Infections in the Pathogenesis of Acute Coronary , 2013 , Philip F. Binkley ,Glen E. Cooke ,Amanda Lesinski, Mackenzie Taylor, Min Chen, Bryon Laskowski, W. James Waldman, Maria E. Ariza, Marshall V. Williams Jr, Deborah A. Knight, Ronald Glaser, 8(8): 2013 Jan.

9. www.rapidtest.com, Human Cytomegalovirus IgG (CMV IgG) ELISA Test kit, Catalog \# : 1201-11 and Human Epstein Barr Virus Early Antigen (EA) IgG ELISA Test Kit , Catalog \# : 1415-11. (Diagnostic Automation Company - USA).

10. J Infect Dis , CMV \& Cardiovascular Disease, 2013, Cécile Courivaud \& Didier Ducloux,208 (8): (2013),1349-1350.

11. Ophthalmology J, Risk of Cataract in Persons with Cytomegalovirus Retinitis and the Acquired Immune Deficiency Syndrome, 2012 , Kempen JH1, Sugar EA, Lyon AT, Lewis RA, Jabs DA, Heinemann MH, Dunn JP, 119(11), 2012 Nov, 2343-50.

12. PLoS Pathog, Cytomegalovirus Infection Causes an Increase of Arterial Blood Pressure, 2009, Jilin Cheng, Qingen Ke, Zhuang Jin, Haibin Wang, Olivier Kocher, James P. Morgan, Jielin Zhang, and Clyde S. Crumpacker, 5(5), 2009 May.

13. American Journal of Epidemiology, Human Cytomegalovirus, Inflammation, Cardiovascular Disease, and Mortality Invited Commentary,2010, Clyde S. Crumpacker,: Vol. 172, No. 4, July 21, 2010, 372-4.

14. Iraqi Journal of Science, The Correlation between CMV Infection and Hypertension in Iraqi Patients, 2015, Raghad G. Al-Suhail, Noor L. Saadoon, Dunya F. Salloom, , Vol 56, No.2B, 2015, pp: 1303-1309.

15. Laboratory Investigation, Increased expression of (pro) renin receptor does not cause hypertension or cardiac and renal fibrosis in mice, 2014, Alva Rosendahl, Gianina Niemann, Sascha Lange, Erfan Ahadzadeh, Christian Krebs, Aurelie Contrepas, Harry van Goor, Thorsten Wiech, Michael Bader, Michael Schwake, Judith Peters, Rolf Stah, Genevie`ve Nguyen and Ulrich O Wenzel, 94, (2014),863-872. 
Study the possible role of CMV and EBV infections to initiate high blood pressure in some groups of hypertensive Iraqi patients

\section{Jasim M. Muhsin}

16. J Clin Virol, Detection of herpes simplex virus, cytomegalovirus and epstein-barr virus DNA in atherosclerotic plaques and in unaffected bypass grafts, 2005, Ibrahim AI1, Obeid MT, Jouma MJ, Moasis GA, Al-Richane WL, Kindermann I, Boehm M, Roemer K, Mueller-Lantzsch N, Gärtner BC, 32 (1) , (2005) , 29-32.

17. Herpesviridae J., High prevalence of human cytomegalovirus in carotid atherosclerotic plaques obtained from Russian patients undergoing carotid endarterectomy,2013, Koon-Chu Yaiw, Olga Ovchinnikova, Chato Taher, Abdul-Aleem Mohammad, Belghis Davoudi, Eugene Shlyakhto, Oxana Rotar, Alexandra Konradi, Vanessa Wilhelmi, Afsar Rahbar, Lynn Butler, Alice Assingerand Cecilia Söderberg-Nauclér, 14;4(1): 2013 Nov.

18. Nature 506 , "Scientific method: Statistical errors", 2014, Nuzzo, R. (2014).(7487): 150-152. 